\title{
Zebra lines in osteogenesis imperfecta on bisphosphonate therapy
}

\author{
Suja P Sukumar, Karthik Balachandran, Jaya Prakash Sahoo, \\ Sadishkumar Kamalanathan
}

Department of Endocrinology, Jawaharlal Institute of Post Graduate Medical Education \& Research, Puducherry, India

\section{Correspondence to}

Dr Sadishkumar Kamalanathan, sadishkk@gmail.com
To cite: Sukumar SP, Balachandran K, Sahoo JP, et al. BMJ Case Rep Published online: [please include Day Month Year] doi:10.1136/bcr-2012008536

\section{DESCRIPTION}

A 7-year-old girl presented with a history of recurrent fractures since the age of 1 month. She was born out of a non-consanguineous marriage and had short stature with macrocephaly and triangular facies. Her sclera and teeth were normal. She did not have any hearing defect or a family history of frequent fractures. Her biochemical metabolic profile was normal except for vitamin D deficiency which was corrected. She was provisionally diagnosed as having osteogenesis imperfecta type IV of Sillence's classification ${ }^{1}$ and initiated on cyclic pamidronate therapy to reduce the rate of fractures. ${ }^{2}$ She, however, had a repeat fracture in her right shaft of femur during the course of therapy.

Her current follow-up skeletal imaging revealed four metaphyseal bands of increased density paralleling the contours of the physis in the distal femur, proximal tibia and proximal fibula, matching the number of treatment cycles she had undergone (figure 1). These metaphyseal bands, alternately described as 'zebra lines', ${ }^{3}$ vary in spacing according to the age of the patient, rate of growth and the location of the metaphysis. Differential remodelling due to cyclic antiosteoclastic activity of bisphosphonates leads to these 'zebra lines' corresponding to alternative periods of increased and normal bone mineralisation. The prognostic significance of these lines during therapy is currently restricted to serving as a marker of the course of prior bisphosphonate treatment received. The prognosis of this condition depends on the type of osteogenesis imperfecta, the genetic defect producing it and the treatment given.

\section{Learning points}

Zebra lines are metaphyseal bands of increased density observed near the ends of long bones during cyclic bisphosphonate therapy in osteogenesis imperfecta.

- They are most prominently seen around knee and elbow joints.

- They serve as a marker of the course of prior bisphosphonate treatment received.

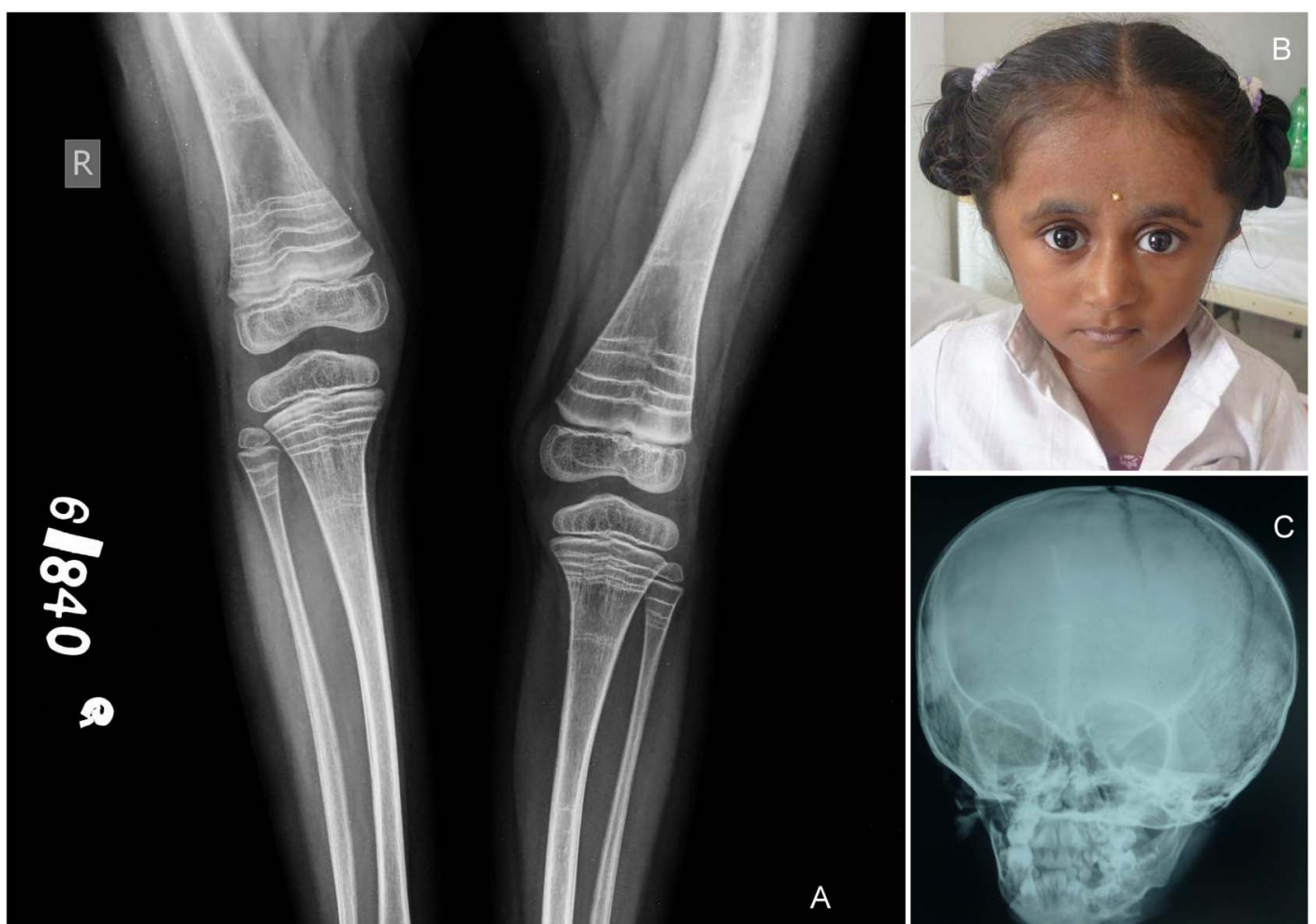

Figure 1 (A) x-Rays of bilateral knee joints showing 'zebra lines' in distal femur, proximal tibia and proximal fibula. (B) Gross facial phenotype of osteogenesis imperfecta child depicting triangular facies and macrocephaly. (C) X-ray of the skull of osteogenesis imperfecta child showing macrocephaly. 
Competing interests None.

Patient consent Obtained.

Provenance and peer review Not commissioned; externally peer reviewed.

\section{REFERENCES}

1 Sillence D. Osteogenesis imperfecta: an expanding panorama of variants. Clin Orthop Relat Res 1981;159:11-25.

2 Glorieux FH, Bishop NJ, Plotkin $\mathrm{H}$, et al. Cyclic administration of pamidronate in children with severe osteogenesis imperfecta. N Engl J Med 1998;339:947-52.

3 Al Muderis M, Azzopardi T, Cundy P. Zebra lines of pamidronate therapy in children. J Bone Joint Surg Am 2007;89:1511-16.

Copyright 2013 BMJ Publishing Group. All rights reserved. For permission to reuse any of this content visit http://group.bmj.com/group/rights-licensing/permissions.

BMJ Case Report Fellows may re-use this article for personal use and teaching without any further permission.

Become a Fellow of BMJ Case Reports today and you can:

- Submit as many cases as you like

- Enjoy fast sympathetic peer review and rapid publication of accepted articles

- Access all the published articles

- Re-use any of the published material for personal use and teaching without further permission

For information on Institutional Fellowships contact consortiasales@bmjgroup.com

Visit casereports.bmj.com for more articles like this and to become a Fellow 